\title{
Short communication: Bulk milk somatic cell penalties in herds enrolled in Dairy Herd Improvement programs
}

\author{
K. J. Hand, ${ }^{* 1}$ M. A. Godkin, $†$ and D. F. Kelton‡ \\ *Strategic Solutions Group, Puslinch, ON, Canada, NOB 2JO \\ †Ontario Ministry of Agriculture, Food and Rural Affairs, Elora, ON, Canada, NOB 1S0 \\ $\ddagger$ Population Medicine, University of Guelph, Guelph, ON, Canada, N1G 2W1
}

\begin{abstract}
The objective of this study was to determine the effect of somatic cell count (SCC) monitoring at the cow level through Dairy Herd Improvement (DHI) programs on the risk of bulk tank SCC (BTSCC) penalties. For the year 2009, BTSCC for all producers in Ontario were examined, for a total of 2,898 DHI herds, 1,186 nonDHI herds, and 48,250 BTSCC records. Two penalty levels were examined, where BTSCC exceeded 499,000 (P500) and 399,000 (P400) cells/mL. Data were modeled first to determine the odds of a BTSCC exceeding a set penalty threshold and second to determine the odds of incurring a penalty under the Ontario Milk Act. All data were modeled as a generalized mixed model with a binary link function. Random effects included herd, fixed effects included season of BTSCC (summer, May to September, and winter, October to April), total milk shipped per month (L), fat paid per month (kg), protein paid per month $(\mathrm{kg})$, and participation or not in the DHI program. The likelihood of a BTSCC exceeding a penalty threshold in a non-DHI herd compared with a DHI herd was significantly greater than 1 at both penalty levels, where the odds ratios were estimated to be 1.42 [95\% confidence interval (CI): 1.19 to 1.69 ] and 1.38 (95\% CI: 1.25 to 1.54 ) for P500 and P400, respectively. The likelihood of incurring a BTSCC penalty (where 3 out of 4 consecutive BTSCC exceeded penalty thresholds) was not significantly different at P500; however, it was significantly different for P400, where the odds ratio was estimated to be 1.42 (95\% CI: 1.12 to 1.81 ).
\end{abstract}

Key words: bulk milk somatic cell count, dairy herd improvement, bulk milk quality, odds ratio

\section{Short Communication}

Dairy industries throughout the developed world produce high-quality milk products for consumption and

Received June 20, 2011.

Accepted September 29, 2011.

${ }^{1}$ Corresponding author: Karen.hand@strategicsolns.ca processing. High-quality milk products are sustained by the implementation of regulations that focus on the monitoring of milk levels of bacteria, inhibitors, and somatic cells in the commingled bulk tank milk. Specifically, dairy markets worldwide have set regulatory upper limits for bulk tank somatic cell count (BTSCC). Regulatory limits for BTSCC vary across countries. In the European Union, the regulatory limit is $400 \times$ $10^{3}$ cells $/ \mathrm{mL}$. The federal limit in the United States is $750 \times 10^{3}$ cells $/ \mathrm{mL}$, except in California, which has a limit of $600 \times 10^{3}$ cells $/ \mathrm{mL}$. Current regulatory limits for Australia, New Zealand, Norway, and Switzerland are $400 \times 10^{3}$ cells $/ \mathrm{mL}$. In Ontario, Canada, a 6 -yr reduction program was implemented in 1989, resulting in the current regulatory limit of $500 \times 10^{3}$ cells $/ \mathrm{mL}$ (OMAFRA, 1990). However, Ontario will soon follow the European Communities: on August 1, 2012, the regulatory limit will be lowered to $400 \times 10^{3}$ cells $/ \mathrm{mL}$.

Clearly, the management of BTSCC levels on dairy farms should be a major focus for dairy producers. Schukken et al. (1992a) found that BTSCC management practices were closely associated with the improvement of other milk quality indicators, such as microbial inhibitor scores and freezing point deviators. In a study of BTSCC dynamics, Schukken et al. (1992b) suggest that dairy industries must encourage producers with low BTSCC to maintain those low levels, which is as important as decreasing BTSCC on farms with high BTSCC. Other studies confirm the importance of maintaining low BTSCC and suggest that monetary incentives should be paid to producers who do so (Sargeant et al., 1998; Nightingale et al., 2008). Dekkers et al. (1996) found that efforts to reduce BTSCC resulted in substantial economic gain. Further, Raubertas and Shook (1982) quantified milk production loss due to SCC, with milk loss increasing from 135 to $270 \mathrm{~kg}$ per unit increase in average log cell count, depending on lactation. Management of BTSCC is aided by frequent monitoring of cow SCC through participation in DHI programs. In Ontario, participation in DHI has steadily increased, with $75 \%$ of dairy herds participating in 2010 (CanWest DHI, 2010). 
Table 1. Summary of odds ratios comparing non-DHI herds to DHI herds for penalty levels P500 and P400

\begin{tabular}{llcccc}
\hline & & & \multicolumn{2}{c}{$95 \%$ CI } \\
\cline { 4 - 6 } Penalty $_{\text {level }^{1}}$ & Description & $\begin{array}{c}\text { Estimated } \\
\text { odds ratio }\end{array}$ & $P$-value & Lower limit & Upper limit \\
\hline P500 & Bulk tank SCC exceeds threshold & 1.42 & $<0.0001$ & 1.19 & 1.69 \\
& Producer incurs penalty & 1.79 & 0.11 & 0.89 & 3.65 \\
P400 & Bulk tank SCC exceeds threshold & 1.42 & $<0.004$ & 1.25 & 1.54 \\
& Producer incurs penalty & 1.42 & 0.004 & 1.12 & 1.81 \\
\hline
\end{tabular}

${ }^{1}$ P500 occurred when bulk tank SCC exceeded a threshold value of 499,000 cells/mL (the current Ontario penalty level), and P400 occurred when bulk tank SCC exceeded a threshold value of 399,000 cells $/ \mathrm{mL}$ (the penalty level due to be implemented in August 2012).

For the purpose of this study, participation in DHI programs with access to cow-level SCC records assumes utilization by the producer. The objective of this study was to determine if having access to cow-level SCC through DHI programs was associated with a decreased risk of BTSCC penalties.

To assess the benefit of participation in DHI and having access to cow-level SCC, odds of a BTSCC (calculated as the weighted average of 4 observations per month) exceeding penalty thresholds, as well as the likelihood of incurring a BTSCC penalty were calculated for herds enrolled in a DHI program compared with those that were not enrolled. In this study, BTSCC were collected for 4,084 Ontario dairy herds in 2009, where 2,898 of the herds were enrolled in the CanWest DHI program and 1,186 were not. CanWest DHI herds shipped, on average, 48,000 L of milk per month compared with non-DHI herds, which had a monthly average of 49,000 L. In 2009, the percentage of DHI and non-DHI herds with milk level freezing point and bacteria count penalties fell below $0.5 \%$. Milk-level bacteria inhibitor penalties for both participatory groups was less than $0.07 \%$. The 25 th, 50 th, and 75 th percentiles for BTSCC in CanWest DHI herds were found to be 164,228 , and $309 \times 10^{3}$ cells $/ \mathrm{mL}$, respectively, and those for BTSCC in non-DHI herds were found to be 179,250 , and $339 \times 10^{3}$ cells $/ \mathrm{mL}$, respectively. For each BTSCC record, total milk shipped (L), fat paid $(\mathrm{kg})$, and protein paid $(\mathrm{kg})$ were recorded. Season of observation was also recorded, in which summer was defined for any record collected between May and September and winter otherwise. All BTSCC records were further coded with respect to whether a given BTSCC exceeded a given penalty threshold or not, as well as whether a producer incurred a BTSCC penalty (3 out of 4 consecutive monthly BTSCC exceed penalty thresholds) as per the Ontario Milk Act (OMAFRA, 1990). Two penalty levels were modeled. Penalty level 1 (P500) occurred when BTSCC exceeded a threshold value of 499,000 cells/mL (the current Ontario penalty level) and penalty level 2 (P400) occurred when BTSCC exceeded a threshold value of 399,000 cells $/ \mathrm{mL}$ (the penalty level due to be implemented in August 2012).

In total, 48,250 BTSCC records were available. Data were modeled as a generalized linear model using PROC GLIMMIX in SAS version 9.2 (SAS Institute, 2009) with a binary link function. Random effects included herd, where the error structure accounted for repeated observations within a herd. Fixed effects included season (summer and winter), DHI (0 for non-DHI herds, 1 for DHI herds), total milk shipped per month (L), and total fat and protein paid per month $(\mathrm{kg})$.

The odds of a BTSCC exceeding penalty thresholds at P500 and P400 in a non-DHI herd compared with a DHI herd were found to be significantly greater than 1 $(P<0.0001$ and $P<0.004$, respectively). At P500, the odds ratio was estimated to be 1.42 with a $95 \%$ CI from 1.19 to 1.69 ; at $\mathrm{P} 400$, the odds ratio was estimated to be 1.38 with a $95 \%$ CI from 1.25 to 1.54 . A summary of the odds ratios can be found in Table 1 .

The odds of a producer incurring a BTSCC penalty at P500 was not significantly different between DHI producers and non-DHI producers $(P=0.11)$. However, the odds of a producer incurring a BTSCC penalty at P400 was significantly greater for non-DHI producers than for DHI producers $(P=0.0040)$; the odds ratio was estimated to be 1.42 with a $95 \%$ CI from 1.12 to 1.81 (Table 1).

In conclusion, we demonstrated a benefit of being enrolled in a DHI program and having access to cow-level SCC to manage BTSCC, such that DHI herds were $30 \%$ less likely to exceed BTSCC penalty thresholds at a regulatory limit of 500,000 cells $/ \mathrm{mL}$ and $28 \%$ less likely to exceed BTSCC penalty thresholds at a regulatory limit of 400,000 cells/mL. Furthermore, DHI producers were $30 \%$ less likely to incur BTSCC penalties in Ontario for a regulatory limit of 400,000 cells/mL.

\section{ACKNOWLEDGMENTS}

Financial support for this study was provided by CanWest DHI (Guelph, ON, Canada). The data for 
this study were provided by CanWest DHI (Guelph, ON, Canada) and the Dairy Farmers of Ontario (Mississauga, ON, Canada). The authors thank Ian Rumbles and Richard Canton of CanWest DHI (Guelph, ON, Canada) for all their assistance in the production of this paper.

\section{REFERENCES}

CanWest DHI. 2010. DHI participation hits $75 \%$ milestone in Ontario [News release]. CanWest DHI, Guelph, Ontario, Canada.

Dekkers, J. C. M., T. Van Erp, and Y. H. Schukken. 1996. Economic benefits of reducing somatic cell count under the milk quality program of Ontario. J. Dairy Sci. 79:396-401.

Nightingale, C., K. Dhuyvetter, R. Mitchell, and Y. Schukken. 2008 Influence of variable milk quality premiums on observed milk quality. J. Dairy Sci. 91:1236-1244
OMAFRA. 1990. The Milk Act and Regulations of Ontario. Ontario Ministry of Agriculture, Food and Rural Affairs, Toronto, Ontario, Canada.

Raubertas, R. F., and G. E. Shook. 1982. Relationship between lactation measures of somatic cell concentration and milk yield. J. Dairy Sci. 65:419-425.

Sargeant, J. M., Y. H. Schukken, and K. E. Leslie. 1998. Ontario bulk mik somatic cell reduction program: Progress and outlook. J. Dairy Sci. 81:1545-1554.

SAS Institute. 2009. SAS User's Guide. Statistics. Version 9.2. SAS Institute Inc., Cary, NC.

Schukken, Y. H., K. E. Leslie, A. J. Weersink, and S. W. Martin. 1992a. Ontario bulk milk somatic cell count reduction program. 1. Impact on somatic cell counts and milk quality. J. Dairy Sci. 75:3352-3358.

Schukken, Y. H., K. E. Leslie, A. J. Weersink, and S. W. Martin. 1992b. Ontario bulk milk somatic cell count reduction program. 2. Dynamics of bulk milk somatic cell counts. J. Dairy Sci. 75:33593366 . 